\title{
A COMPREHENSIVE STRATEGIC PARTNERSHIP: SYNCHRONIZING CHINA'S BELT AND ROAD INITIATIVE (BRI) ON RUSSIA'S EURASIA ECONOMIC UNION (EAEU)
}

\author{
Hendra Manurung \\ International Relations, President University, Cikarang, Indonesia \\ h_manurung2002@president.ac.id
}

\begin{abstract}
This research attempts to enrich debate by addressing the relationship of the China's Belt and Road Initiative with the Russia's Eurasian Economic Union (EAEU). Currently, it is a common phenomenon where a regional economic grouping bringing together several of China's important BRI partners including Russia and Central Asian countries. Since 2013, China's Belt and Road Initiative (BRI) initiated, developed, and has been promptly placed among the top priorities of China's foreign policy consideration in Beijing. One of the BRI's cooperation priorities is unimpeded trade, which implies the improvement of the investment and trade facilitation and removal of the recurrent investment and trade barriers. Despite its apparent flexibility and openness to embracing existing regional and multilateral platforms, there has been little debate on the compatibility of the BRI objectives with the existing economic integration projects. Thus, it raises a question on how these two initiatives go along smoothly, why it needs to be developed and how it will be develop. Meanwhile, it exists also the U.S-China trade war which has been going intensively for two years since 2017. It addresses the current progress in bridging the two major economic projects and outlines the strategic decision-making priority directions for further coordination between these two global major powers.
\end{abstract}

Keywords: China, Russia, belt and road initiative, Eurasia economic union, strategic decision

DOI: $10.33541 /$ sp.v20i2.1442

Sociae Polites : Majalah Ilmiah Sosial Politik

Faculty of Social and Political Science, Universitas Kristen Indonesia

ISSN 1410-3745 print/ ISSN 2620-4975 online

Volume 20, Number 2 (July - December 2019)

Pages 164-178 


\section{Introduction}

There are many regional integration and cooperation mechanisms and initiatives in Eurasia, of which the most influential is undoubtedly the Belt and Road Initiative (BRI) proposed by China. Nearly 160 countries and international organizations have signed partnership agreements with China. As far as post-Soviet space is concerned, the highest level of integration is represented by the Russian-led Eurasian Economic Union (EAEU).

For over seventy years, China and Russia have played active roles in international affairs and global governance, and made important contributions to maintaining world peace and stability as well as international fairness and justice. In Moscow, on 5 June 2019, China and Russia agreed to upgrade their relations to a comprehensive strategic partnership of coordination for a new era. The decision was made at a meeting between visiting Chinese President $\mathrm{Xi}$ Jinping and his Russian counterpart, Vladimir Putin (XINHUA.NET, 6 June 2019). In Kremlin, the two heads of state highly evaluated the development of bilateral ties over the past 70 years (1949-2019), agreed to uphold the notion of good neighborliness and win-win cooperation, develop a comprehensive strategic partnership of coordination for a new era in a bid to take bilateral ties to a higher level and better benefit the peoples of the two countries and the world as well.

On April 25 to 27, 2019, the $2^{\text {nd }}$ Belt and Road Forum (BRF) for International Cooperation held in Beijing and attended by Russian President, Vladimir Putin. The Chinese President Xi Jinping also officially invited Austrian Chancellor Sebastian Kurz, Chilean President Sebastian Pinera, Indonesia Vice President, Jusuf Kalla, Laos President Bounnhang Vorachith, Mongolian President Khaltmaa Battulga, Nepali President Bidya Devi Bhandari, Portuguese President Marcelo Rebelo de Sousa and President of the Swiss Confederation Ueli Maurer joined 2019 event and pay state visits to China respectively (CGTN, 19 April 2019). There are 37 heads of state or government and other leaders from Austria, Egypt, Italy and Laos attended the forum. France, Germany, the UK, Spain, Japan, South Korea and the EU also sent high-level representatives to the forum.

The Chinese State Councilor and Foreign Minister Wang Yi declared significantly that 126 countries and 29 international organizations have signed cooperation agreements with China to jointly build the Belt and Road (CGTN, 19 April 2019). Up to April 2019, the total trade volume between China and participating countries has surpassed USD 6 (six) trillion, investment has exceeded USD 80 billion, and the 82 cooperation parks built by China and relevant countries have created nearly 300,000 jobs, bringing enormous development opportunities for the countries involved and laying a solid foundation for China to host the second Belt and Road Forum. Since 2017, the Belt and Road with concerted efforts is becoming a clean road for cooperation, prosperity, openness, green development and win-win outcome that will benefit people of all countries.

The $2^{\text {nd }}$ BRF aims to bring about high-quality cooperation under the Belt and Road framework, through specific theme of "Belt and Road Cooperation, Shaping a Brighter Shared Future". The BRF is the highest level platform for international cooperation under the Belt and Road framework and is the most important event China hosted formally.

The construction of the China One Belt and One Road should implement an innovative cooperation model, which, at the current stage, is not a supranational mechanism, nor a model at the same level with the Customs Union or the Economic Union (Feng \& Wang, 2015, p. 35).

The Chinese President, Xi Jinping, announced the launch of the Silk Road Economic Belt (Laruelle, 2015a; 2015b; Peyrouse \& Raballand, 2015) at Nazarbayev 
University in Astana during his visit to Kazakhstan in September 2013 (Ministry of Foreign Affairs of the People's Republic of China, 7 September 2013).

Meanwhile, the Maritime Silk Road was subsequently unveiled at the Indonesian Parliament in Jakarta during his visit to Indonesia in October 2013 (Yong Wang, 2016). Jointly labeled as the "Belt and Road Initiative" (hereinafter: BRI), this cooperation initiative, if fully realized, would bring together over $70 \%$ of the world's population, which accounts for about 55\% of global GDP and has about $75 \%$ of discovered energy reserves (World Economic Forum, 22 September 2015). The BRI has been promptly placed among the top priorities of China's foreign policy, which were discussed at the Peri- phery Diplomacy Work Forum in October 2013, shortly after President Xi returned from his visit to Indonesia (see generally: Swaine, 2014; Swaine, 2015a). Chinese scholars analysing the media response to the BRI indicate a significant increase in BRIrelated studies after the plans were crystallized in 2014 (Min Ye, 2015, p. 217; Swaine, 2015b).

\section{Pan Regional Cooperation Initiative: Connecting China BRI \& Russia Eurasia}

Judging from the nature of the two initiatives, there is no contradiction in principle between the BRI and the EAEU. The Eurasian Economic Union is a highly integrated organization with complete mechanisms for decision-making, implementation and resolution of differences. And the BRI is a pan-regional cooperation initiative, a cooperation platform without an entry bar and with strong inclusiveness. There is no fundamental conflict between the two, which serves as the basis for their connection.

Based from the internal and external environment, the connection of the two initiatives is the result of strategic thinking by China and Russia. It is inevitable rather than just a tactical compromise made by the two countries to create an atmosphere for strategic partnership. At least there are two major reasons for both countries to connect and integrate this economic cooperation into reality.

First of all, changes in the external environment require closer cooperation between China and Russia. The most prominent change is that the U.S uses fair and free trade as the pretext to build a small circle that excludes China and Russia through bilateral negotiations and to reconstruct a new trade order dominated by the U.S and other developed countries. While, based on the perspective of geopolitics, the U.S strategy of containing China and Russia will not change. China and Russia do not want to spoil their relations with the U.S. However, the two countries also know very well that it is much easier to fall foul of the United States than get along well with it.

Secondly, the Eurasian Economic Union desires to strengthen cooperation with the outside world. From a technical point of view, the economies of the member countries of the union are homogeneous and the transfer of production is limited. For example, Russia, Belarus and Kazakhstan are all energy and chemical producers and exporters.

There is a demand for raw materials trading, but there is also competition rather than complementarity in terms of finished products. As the largest economy in the EAEU, Russia has neither the capital to invest abroad nor the extra production capacity to be transferred abroad. Therefore, countries in the union place their hopes for economic development on the outside world. In February 2016, President Nazarbayev proposed to designate 2016 as the year to deepen the economic relations of the Union with third countries and key trade blocs, which reflects the union's desire to strengthen economic and trade ties with the outside world (Li Ziguo, 2019). 
However, among the potential partners, all countries regard China, which has abundant foreign exchange reserves and is eager to go global, as the ideal pick.

On 28 March 2015, with the endorsement of the State Council (The State Council of the People's Republic of China, 2015), the National Development and Reform Commission, the Ministry of Foreign Affairs, and the Ministry of Commerce (MOFCOM) jointly released the Action Plan on the Belt and Road Initiative.

In fact, the BRI Action Plan labels this initiative a positive endeavor to seek new models of international cooperation and global governance (BRI Action Plan - Section I Background, 2015). It specifies that the initiative will abide by market rules and international norms so that the market will play a decisive role in resource allocation (BRI Action Plan - Section II Principles, 2015).

Therefore, it calls for the development of the Eurasian Land Bridge via three economic corridors: 1) China-Mongolia- Russia; 2) China-Central Asia West Asia; and 3) China-Indochina Peninsula (BRI Action Plan - Section III Framework, 2015). Some International Relations scholars have quickly labeled the BRI vision documents as Sinocentric "extension, consolidation and political elevation of pre-existing policy ideas and practice at the sub-national level in China" (Summers, 2016, p. 1634). After comparison with other initiatives such as the Trans-Pacific Partnership (TPP), the Regional Comprehensive Economic Partnership (RCEP), or the US-led New Silk Road, it was suggested that China's new Silk Road has long-built political and developmental aspirations in the region that could not be met with alternative frameworks (Min Ye, 2015, p. 222).

One of the BRI's cooperation priorities is unimpeded trade, which implies the improvement of the investment and trade facilitation and removal of the recurrent investment and trade barriers. The BRI Action plan also provides for the opening of free trade areas (Lin, 2015). The countries along the BRI are encouraged to enhance customs cooperation and to ratify and implement the WTO Trade Facilitation Agreement (Trade Facilitation Agreement, December 2013). The initiative calls for the lowering of nontariff barriers, improving the transparency of technical trade measures, enhancing trade liberalization and facilitation (BRI Action Plan - Section IV Unimpeded Trade, 2015).

It could be some cooperation mechanisms envisaged by the BRI in order to achieve the aforementioned objectives. However, what sort of regulatory framework should be established for the legal support of the BRI connectivity projects? Suppose, the BRI Action plan provides for engagement in the bilateral and multilateral cooperation mechanisms.

It echoes the approach adopted at the $18^{\text {th }}$ National Congress of the Communist Party of China: "Multilateral, bilateral, and regional opening ups and co- operation are the three important pillars of the Chinese foreign economy, trade, and cooperation" (Feng $\&$ Wang, 2015, p. 57). It means a platform for further dialogue and cooperation on many levels, engaging, if necessary, the existing governance structures, which is not a union or new organization with supra-national structures. The platform development has been echoed in the Macao SAR Five Year Development Plan (2016-2020) which expressly mentions the influence by the BRI and the China's Five Year Plan (Macao SAR 5 Year Development Plan, 2016-2020) As noted by President Xi in his keynote speech "Towards a Community of Common Destiny and A New Future for Asia" delivered at the 2015 Boao Forum for Asia in Hainan, "To develop the Belt and Road is not to replace existing mechanisms or initiatives for regional cooperation. Much to the contrary, we will 
build on the existing basis to help countries align their development strategies and form complementarity" (Boao Forum for Asia Annual Conference, 2015).

Thus, while the buildup of the BRI cooperation platform and mechanisms is still an ongoing process, the contributions from various stakeholders such governmental and non-governmental, national and multinational, public and private in various disciplines can contribute to their development. While the implementation of the BRI has been addressed in academic circles of political science (Blanchard \& Flint, 2017), international relations (Yong Wang, 2016), economics and business (Haiyue Liu, Yingkai Tang, Xiaolan Chen \& Poznan- ska, 2017), relatively little attention has been accorded to the legal founda- tions for the envisaged cooperation mechanisms (Wolff \& Chao Xi (eds), 2016; Wang, 2017).

The bilateral interactions of individual countries with China within the framework of BRI cooperation have been discussed in comparative length (Ghouri, A., 2016, p. 3668 ) while the discussion on its interaction with the existing economic integration projects has not yet been sufficiently developed (Haitao Huang, 2017, p.45-59). The present paper is aimed at enriching the debate by addressing the relationship of the BRI project with the Eurasian Economic Union (EAEU), a regional economic grouping bringing together several of China's important BRI partners.

\section{The Contribution of BRI on EURASIA}

It is precisely because of the strategic need for connection that the process has been very smooth. It takes only three years for such a connection to be fully realized from the time the idea was put forward. On May 8, 2015, China and Russia signed the Joint Statement on Cooperation on the Construction of Joint Eurasian Economic Union and the Silk Road Projects (Li Ziguo, 2019). China supports the Russia-led Eurasian Economic Union while Russia formally and explicitly supports China's Silk Road Economic Belt Initiative.

If the above statement is only a preliminary plan for the general direction of cooperation and is more of a political gesture, then one year later, in June 2016, a joint statement of the Eurasian Economic Commission (EEC) and the Ministry of Commerce of the People's Republic of China (PRC) on the principal conclusion of negotiations on the agreement on trade and economic cooperation was signed (Li Ziguo, 2019). It indicates that both sides hope to speed up the process of integration and cooperation in the context of the reconstruction of the international political and economic order and will carry out substantive measures rather than just talk show.

Meanwhile, in October 2016, the two sides held the first round of negotiations. In October 2017, the two sides concluded negotiations. On May 17, 2018, the Agreement on Trade and Economic Cooperation between the EAEU and China was signed, covering 13 chapters, including customs cooperation and trade facilitation, intellectual property rights, departmental cooperation, e-commerce and government procurement. It marked that the economic and trade cooperation between China and the EAEU countries entered a new stage driven by projects. In December 2018, the economic and trade cooperation agreement entered into force.

At the heart of the connection between the BRI and EAEU is the mutual coordination of China's and Russia's economic interests in Eurasia and the search for the greatest common denominator for the interests of all parties after taking into account the 
demands of member states. The connection will bring tangible benefits to the BRI and EAEU countries.

For China, the political significance is that it dispels the worries of the entire Eurasian region so that countries don't have to worry about the need to choose between China and Russia. The economic significance is that it provides institutional arrangements for customs facilitation and e-commerce, which is conducive to the exchange of goods and personnel.

Thus, for EAEU member states, the connection can better attract Chinese investment and accelerate the implementation of joint projects. More importantly, it can help EAEU countries access China's huge market, especially in agricultural produce. Connection is a process without an endpoint. It is necessary to find an optimal point in the continuous running-in process so as to minimize the institutional cost for cooperation between China and EAEU member states, accelerate the landing of projects and ultimately benefit the people of all countries.

\section{The Eurasian Economic Union as Eurasian Integration Interest}

It is this narrative of a functional, rules-based integration that explains the EAEU's appeal to various European politicians, officials and experts. In looking for pragmatic solutions to tensions between Russia and the EU, some scholars believe that the EAEU may contribute to the creation of the much coveted ideal of a free trade area from Lisbon to Vladivostok that could act as a ready-made tool for peace and prosperity (Dragneva \& Wolczuk, 2017).

In fact, the origins of the EAEU should be traced back to 1999 when the Russian Federation and the Republic of Belarus entered into an agreement to establish a union between the two countries (Treaty on the Establishment of the Eurasian Economic Community, 10 October 2000). By 2000, the project had been joined by the Republic of Kazakhstan, the Kyrgyz Republic and the Republic of Tajikistan transforming it into the Eurasian Economic Community (EurAsEC). This agreement concerns the creation of the united customs territory and the creation of the Customs Union on 6 October, 2007.

Thus, economic integration had been prompted by, among other things, the disastrous impact of the market-oriented economic policies on the post-Soviet economies (Dzarasov, 2016). The next step envisaged by the members of the EurAsEC was the creation of the Common Economic Space, which was supposed to include Russia, Belarus, Kazakhstan and Ukraine. This initiative, however, was short-lived due to the orange revolution in Ukraine in 2004 (Katchanovski, 2008). As a result, the 2007 Agreement establishing a Customs Union was concluded by Russia, Belarus and Kazakhstan (The Customs Union, 6 October, 2007).

The Agreement established the Customs Union Commission in order to monitor and foster the processes of economic integration. In January 2010 the common customs tariff was implemented at the external borders of the Customs Union. The Eurasian Economic Commission, the first supra-national organization established in this region after the disintegration of the USSR, was headquartered in Moscow. The year 2015 saw the establishment and the enlargement of the EAEU to also include the Republic of Armenia and the Republic of Kyrgyz. On 29 May 2015 the EAEU concluded its first free trade agreement with the Republic Socialist of Vietnam (FTA EAEU-Vietnam, 29 May 2016). 
The Eurasian Economic Union (EAEU) brings together 182 million people; it occupies first place in crude oil $(14.6 \%)$, second place in natural gas $(18.4 \%)$, six th place in coal $(5.8 \%)$, fourth place in electricity generation $(5.1 \%)$, and fifth place in steel $(4.5 \%$ ); it has $1,605,000 \mathrm{~km}$ of roads (fifth place or $2.5 \%$ ), and $107,000 \mathrm{~km}$ of rail- roads which first place or 7.8\% (Eurasian Economic Commission, 2016).

Decision-making in the EAEU Commission is largely consensus-based with the limited use of qualified majority voting for low level decisions, which on one hand slows down the efficiency of decision-making but on the other relieves the dominance of the bigger players such as Russia (Roberts \& Moshes, 2016). For example, while the EAEU framework contains common competition rules, their enforcement is heavily reliant on the cooperation of the national competition authorities of the member states, which can obstruct the prevention and prohibition of anti-competitive business practices that may have cross-border effects on EAEU trade (Rudomino \& Zakharov, 2014).

Moreover, as a result, the supra-national structures of the EAEU are heavily reliant on the commitment of the national governments while the ideas for supra-national parliamentary integration within the EAEU have not yet found any significant support from the political leadership of its members (Naryshkin, S., 2012).

Since its establishment, the EAEU has been followed by the discussion as to the profitability of this economic integration for each of its members, which are different in size, population and the specifics of their national economies. Generally, it can be argued that Russia's EAEU partners have benefited from the customs union, economically at least, in the following ways: the redistribution of customs tariffs (Andronova, 2016, p. 9) and the increasing use of their transport infrastructure for the transit of Chinese exports towards the EU. The EU-Russia and the U.S-Russia confrontation over Ukraine (Neuwirth \& Svetlicinii, 2016) and Russia's ban on food imports from the EU, the U.S and Ukraine benefited EAEU members such as Belarus, which significantly increased its food exports into Russian markets. There is also evidence of the relocation of Russian companies to Kazakhstan and Belarus due to lower taxes and lower administrative burdens in these jurisdictions (Andronova, 2016, p. 11).

At the same time, the volumes of intra-EAEU trade are currently decreasing. For example, when compared to the period 2000-2014, the share of EAEU trade in the trade volumes of its members has been falling: Russia (7.7\% to $7.1 \%)$, Kazakhstan $(20.8 \%$ to $18.4 \%$ ), Belarus (58.6\% to 23.8\%) (Ibid., p. 14). In 2013, the transit volumes in Russia and Belarus fell, while in Kazakhstan they were on the rise. It was suggested that the transport sector of the EAEU needs a new im- pulse, which should be realized through the development of the transit corridors (Panteleev, Pochtarev \& Chalaja, 2015). EAEU trade can be also characterized as Russia-centered since the trade amongst other EAEU members remains marginal. For other EAEU members Russia is the largest trading partner while China is ranked second (Ustyuzhanina, 2016).

Interestingly enough, the EAEU did not undertake any significant steps towards the development of the internal transport infrastructure, which would facilitate trade flows within the EAEU. While the establishment of the customs union had a positive effect on the volumes of mutual trade (between 2000 and 2013 it grew by 37\%), lately it has been on the decrease due to the devaluation of the Russian currency and falling prices of the energy carriers (Ibid., p. 39). Among other problems of EAEU integration are the absence of diversified exports, the undeveloped transport infrastructure and low volumes of intraEAEU trade (Kukushkina \& Ostrovskaya, 2013). 
Initially, the EAEU was regarded as a costly choice for Central Asian countries as their tariff rates in the customs union had been Russianized i.e. increased up to levels of Russian tariffs. As a result, these countries lost a certain volume of imports from third countries to the benefit of Russian companies. However, after Russia's accession to the WTO, the level of the tariffs fell by 40-50\%. Additionally, the EAEU offered further economic benefits to its members in the form of free movement of la-bour and services, efforts to reduce non-tariff barriers and improve trade facilitation, etc. (Tarr, 2016, pp. 18-19).

At the same time, it should be noted that beyond trade liberalization which reduction and unification of tariffs, there has been little coordination in other policy areas and the top-down approach adopted by the EAEU members for their economic integration has been at least partly responsible for stifling the innovation and competitiveness vis-avis other economic integration blocks such as the EU (Hartwell, 2016). The economic integration scholars have continuously voiced calls for further coordination of industrial policy by establishing an EAEU ministry of economy, creation of EAEU multinationals, and fostering coordination of heavy industries and agriculture (Andronova, 2016, pp. 1819).

The situation in Ukraine has definitely affected both the prospects of further EAEU integration and the tensions amongst its members. For other members the accession of Ukraine could imply the dilution of Russia's decisive influence. It was argued that for EAEU members, Russia is seen both as an unavoidable partner but also a threat (Roberts \& Moshes, 2015, p. 13.). Russia's ban on food imports from the EU/US and other countries (Neuwirth \& Svetlicinii, 2015) was not supported by Belarus and Kazakhstan, with imports flowing through these two EAEU member states (Roberts \& Moshes, 2015, pp. 14-15; Sakwa, 2016, p. 13). It was argued that for Armenia, Belarus, and Kazakhstan the value of the EAEU is significantly reduced if it undermines their relations with third countries (Roberts \& Moshes, 2015, p. 18).

After the Ukraine crisis and the deterioration in EU-Russia and the U.S-Russia relations, the Asian vector received more importance as Russia turned to the East in an attempt to engage more with Greater Asia. As the EAEU was intended to grow from an economic to a geopolitical project, the events in Ukraine are an example of how geopolitics has slowed down the economic development of this ambitious integrationist project (Wilson, 2016, p. 127).

There has also been a drastic change in the rhetoric and narrative of EAEU integration discourse: while prior to the Ukraine crisis it was an all-encompassing cooperation project from Lisbon to Vladivostok or even from Vancouver to Vladivostok, the confrontation with the West over Ukraine changed the dimension to from Murmansk to Hong Kong with Russia's focus on its bilateral relations with China and the Shanghai Cooperation Organization, SCO (Vysotskaya \& Vieira, 2016, p. 570). It was suggested by the Russian Minister of Foreign Affairs, Sergey Lavrov that: "The new union will be open for interested countries to join. We expect it to become a hub effectively connecting Europe and the Asia-Pacific" (Lavrov, 2013, p.6-12).

Russia's actions in relation to Ukraine prompted concerns over sovereignty and territorial integrity in other EAEU members. Nevertheless, despite these tensions, "this organizational format is probably the only way for the smaller states to restrain Russia's actions as the regional hegemon" (Ibid., p. 577). The 2015 public opinion polls conducted in the EAEU member states indicated that citizens of Kyrgyzstan (86\%), Kazakhstan $(80 \%)$ and Russia (78\%) overwhel- mingly support the Eurasian integration processes. 
The population of Armenia (56\%) and Belarus (60\%) demonstrated more skepticism towards EAEU development, while Tajikistan demonstrated the highest support for this regional integrationist project among the non-EAEU countries (Kudaibergenova, 2016, p. 105). In analyz- ing the diverging positions of the Eurasian optimists and Eurasian skeptics, it can be argued that the EAEU project is still justified by the current trends of shifting from a state-centered system to a global system with regional associations of states (Vasilieva \& Lagutina, 2013).

\section{Aligning China BRI into Russia Eurasia}

Kazakhstan President, Nursultan Nazarbayec stated clearly that the dynamics of the world economy, which has entered the fourth industrial revolution, have raised the issue of integrating the integrations. It is the formation of common points of economic growth between the Eurasian Economic Union and the Economic belt of the Great Silk Road which has huge prospects (Nazarbayev, 2016).

China's experience in interacting with the EAEU countries as a group can be traced to the Shanghai Cooperation Organization (SCO). All EAEU members are involved in the works of the SCO. Belarus is an observer state and Armenia is a dialogue partner.

It was established in 2001 by Kazakhstan, China, the Kyrgyz Republic, Russia, Tajikistan and Uzbekistan (Shanghai Cooperation Organization, 2016). At the 2016 SCO Summit in Tashkent, India and Pakistan initiated their process of accession to the SCO, which has been completed at the 2017 SCO Summit in Astana, Kazakhstan. Relations between the SCO and the forerunner to the EAEU, the EurAsEC, began in 2006 with the signing of a memorandum of understanding between the executive secretariat of EurAsEC and the permanent secretariat of the SCO (Eurasian Economic Community, 8 May 2006). The EAEU was initially envisaged as an economic union, leading to further political alignment of its member states.

The SCO, on the other hand, first emerged as a peace-building and border disputes resolution mechanism. The institutional structures of the two organizations are also quite different as EAEU encompasses two supra-national institutions such the Eurasian Economic Commission and the Court.

Meanwhile the SCO functions on an intra-state level through periodic meetings. China has already attempted to promote greater economic integration through the SCO but with limited success as the organization continued to focus primarily on security issues. Since China will continue promoting economic integration in Eurasia, which will involve the EAEU states, it was argued that further coordination between the EAEU and the SCO is inevitable and should be encouraged (Yu Bin, 2015). For example, in 2015 the EAEU and the SCO held a joint business forum in Saint Petersburg where they launched a proposal concerning the development of a common digital space between the members of the two organizations (Eurasian Economic Commission, 18 June 2015).

At their 2016 summit the SCO leaders reaffirmed their support for the BRI and expressed their interest in developing further cooperation along the Great Silk Road in various areas: public health, science and technology, education, environment protection, sports, tourism, and the study and preservation of cultural and natural heritage (Shanghai Cooperation Organization, 23-24 June 2016). Some scholars believe that the significant attempts to establish a meaningful cooperation between the SCO which is a primarily 
security-oriented organization and the EAEU in economic integration could eventually lead to the establishment of a comprehensive Silk Road Union (Kembayev, 2016).

The economic cooperation dialogue between China and the EAEU commenced prior to the announcement of the BRI. On 6 December 2012 the EAEU Commission and the MOFCOM concluded a Memorandum of Understanding concerning cooperation in trade matters (Eurasian Commission, 2012). A decision to start formal negotiations between the EAEU and China on the conclusion of a comprehensive product and transport vehicle information exchange agreement was taken at the end of 2014 (Eurasian Economic Commission, 7 October 2014).

In a joint statement released on 8 May 2015, the EAEU Commission and the MOFCOM announced the launch of negotiations for the conclusion of the trade and economic cooperation agreement between China and the EAEU (Eurasian Economic Commission, 8 May 2015). The free trade arrangement between China and the EAEU can currently only be achieved in relation to trade in goods, as the trade in services and the coordination of such with third countries is left by the EAEU Treaty to its member states (EAEU Treaty, Article 38).

On 8 May 2015 Russia and China issued a joint statement concerning cooperation for conjunction of the EAEU and BRI, where Russia expressed its support for BRI while China agreed with Russian efforts in developing EAEU economic integration (kremlin.ru, 8 May 2015). The parties agreed to cooperate on a bilateral level as well as through the SCO platform. The following directions for cooperation were mapped in the Joint Statement: (1) trade and investment facilitation; (2) joint investment projects; (3) enhancing infrastructure connectivity; (4) free trade agreement between the EAEU and China in a long-term perspective; (5) promotion of SMEs; (6) facilitation of payments in national currencies; (7) cooperation within the Asian Infrastructure Investment Bank, Silk Road Fund, SCO Interbank Consortium; (8) global trade and investment governance (Zeng, 2016). The commitment to docking the BRI with the EAEU was reaffirmed by both parties during President Putin's visit to Beijing in June 2016 (China Ministry of Foreign Affairs, 25 June 2016).

Despite the rapid developments in BRI-EAEU dialogue, the scholars have noted the differences in approaches towards the BRI by the two leading counterparts: Russia and China. In Russia, the Silk Road has traditionally been regarded as a transport infrastructure connecting East and West where Russia would play a key role as the bridge connecting these two parts of the world. The EAEU from the outset had a dualist nature: on one hand it was seen as an extension of Greater Europe" from Lisbon to Vladivostok (kremlin.ru, 2012), but with the rise of China it also received a strong Asian vector (Sakwa, 2016, p. 5).

For China, however, the BRI is primarily a belt rather than a road, meaning a space of economic development and prosperity where highly developed states are engaged in an intensive trade exchange (Makarov \& Sokolova, 2016 pp. 48-50). What makes the $21^{\text {st }}$ century Silk Road different from the ancient one is that today this road passes through sovereign states with different political and economic objectives.

As a constructive result, one of the few issues that all of these Central Eurasian states have unanimously supported was the improvement of border management (Diener, 2015). Since the BRI is essentially based on the increase of various flows of goods, services, and people across those borders, this will present a tremendous challenge for those states inclined to protect their territorial sovereignty. In this sense, the builders of the BRI will have much to learn from the positive experience of the EAEU, which at least 
shares a common history of such flows in the modern era and has to a certain degree progressed in this direction such: free flow of goods, no visa regimes, abolition of border controls, etc.

However, it should be also noted that the establishment of the EAEU was based on WTO standards and used the EU model of institutional integration such EAEU Commission and EAEU Court to indicate the potential of establishing a free trade zone with the EU (Kukushkina \& Ostrovskaya, 2013). A hastening in recognition of the EAEU by the EU would be achieved by the accession of Kazakhstan and Belarus to the WTO (World Trade Organization, 2015).

With the expansion of EU-China trade exchanges, the EAEU may lose sense as a common economic space. But, the success of the BRI will also rest on a good RussiaChina relationship. If these are to deteriorate, Russia will employ frictional policies towards the countries of the Eurasian periphery to increase the costs of their rapprochement with China" (Samokhvalov, 2016). It should be noted that despite the current cordial relations between Russia and China, China's rising power and its overwhelming economic capabilities in comparison with Russia create a growing power disparity and the maintenance of some sort of equilibrium in Russian-Chi- nese interactions is a challenge (Wilson, 2016, p. 114. See also: Grigorenko, Klyuch- nikov, Gridchina, Litvinenko \& Kolpak, 2016).

Moreover, when discussing the rationale of other post-Soviet states that have not joined the EAEU project (Georgia, Moldova, Ukraine, Azerbaijan, Uzbekistan, Turkmenistan) one should note their attempt to avoid Russian influence. But for most of these states the Russian vector is unavoidable so they will inevitably be involved in some sort of economic integration with Russia or its regional initiatives (see e.g.: Korosteleva, 2015).

While, at the same time all of the above countries have expressed their interest in taking part in BRI projects. It was argued that in this context the institutionalization of this process will provide for more stability in the regional policies of the post-Soviet states but does not create conditions for long-term, sustainable development of these projects (Skriba, 2014, p. 95). The BRI should be able to provide such economic cooperation in long-term perspective.

\section{Conclusion}

For physical infrastructure to be successful there is a parallel system of soft infrastructure - laws, policies, practices, and standards that are less easily installed and monitored than physical structures but every bit as important if the physical infrastructures of transportation, communication, and energy are going to be successful.

The EAEU, the SCO and the BRICS group (Brazil, Russia, India, China, and South Africa) have been regarded as the embryo of post-Western order.

The BRI led by China engages numerous members of these economic and political groupings. Up until now, BRI development has been pursued primarily on a bilateral level between China and the interested countries along the envisaged BRI routes. It was argued that the BRI should be viewed primarily as a cooperation platform rather than a formal economic integration model like the EU or the EAEU. Nevertheless, despite its apparent flexibility and openness to embrace the existing regional and multilateral platforms, there has been little debate on the compatibility of the BRI objectives with the existing economic integration projects. It has been an attempt to address the possibility of 
integration of the BRI projects with the existing economic governance framework of the EAEU.

Both the EAEU and the BRI projects have been criticized for the stark inequality of the participating members. The discrepancies in size among member states culminated in palpable state-centric concerns that the EAEU would facilitate Russian hegemony in Central Asia while the BRI and SCO could lay the foundation for Chinese dominance. For the same reasons it could be beneficial for the EAEU members to act together as a stronger negotiating partner with China, and for China it could be a faster step towards a single tariff and single customs zone of the EAEU.

In discussing Eurasian economic integration, Russian scholars noted that one of the intellectual problems of the EAEU is that Russia was always clear about what it builds but not why it builds these structures, and the EAEU project has never been properly addressed by Russian high-ranking officials. The true intentions and possible implications of the BRI project go far beyond economic rationale. In this sense, the promoters of the BRI could learn from the EAEU experience and make sure that non-economic objectives are clearly presented, widely publicized and accepted by the countries that join the initiative.

The envisaged BRI encompasses all EAEU members, which make the interaction of these two economic cooperation and integration platforms inevitable. The scholars have outlined various directions for EAEU development along the BRI such as: 1) integration in the transport and logistics infrastructure of Eurasia, 2) the strengthening of trans-border industrial cooperation, and 3) the enhancement of economic integration up to the establishment of the comprehensive Eurasian Union.

Regardless of its actual path, the integration of integrations in the case of the BRI and the EAEU is a reality and further academic debate on their conjugation should be encouraged. 


\section{BIBLIOGRAPHY}

\section{Books}

Korosteleva, E. (2015). Belarus between the EU and Eurasian Economic Union. In: Dutkiewicz and Sakwa R. (eds.) Eurasian Integration - The View from Within. New York: Routledge.

Neuwirth, R.J., Svetlicinii, A. \& De Castro Halis, D. (eds.) (2017). The BRICS-Lawyers' Guid to Global Cooperation. Cambridge University Press.

Wolff, L. Ch. \& Chao Xi (eds). (2016). Legal Dimensions of China's Belt and Road Initiative, Wolters Kluwer.

Yang, Cheng. (2015). The Eurasian Moment in Global Politics: A Comparative Analysis of Great Power Strategies for Regional Integration. In: Dutkiewicz P. and Sakwa R. (eds). Eura- sian Integration - the View from Within. New York: Routledge.

$\mathrm{Yu}$, Bin. (2015). The Shanghai Cooperation Organisation, China and Eurasian integration. In: Dutkiewicz P. and Sakwa R. (eds). Eurasian Integration - the View from Within, New York: Routledge.

Zongxian Feng \& Hua Wang (2015). The Mode of Economic Cooperation in the "One Belt and One Road" Construction. In: H.G. Djajadikerta and Z. Zhang (eds). A New Paradigm for International Business. Springer.

\section{Official documents}

China Ministry of Foreign Affairs. (2016). Xi Jinping Holds Talks with President Vladimir Putin of Russia Both Heads of State Stress Unswerving Commitment to Deepening China-Russia Comprehensive Strategic Partnership of Coordination, 25 June 2016. Accessed on 23 July 2019 from http://www.fmprc.gov.cn/mfa_eng/ zxxx_662805/t1375791.shtml.

Free Trade Agreement between Eurasian Economic Union and Its Member States and the Socialist Republic of Vietnam on 29 May 2016. Accessed on 28 July 2019 from https://docs.eaeunion.org/docs/ru-ru/0147849/itot_02062015.

Kremlin.ru. (2012). Russian President Vladimir Putin at the meeting with the Russian diplomats has called for the establishment of the common market from Atlantic to the Pacific, 14 August 2012. Accessed on 27 July 2019 from https://kremlin.ru/events/president/news/15902.

Kremlin.ru. (2015). Joint Statement of the Russian Federation and the People's Republic of China on Cooperation in Conjugation of Construction of the Eurasian Economic Union and the Silk Road Economic Belt, 8 May 2015. Accessed on 30 July 2019 from https://www.kremlin.ru/supplement/4971.

Macao SAR Five Year Development Plan, 2016-2020. (2015). Accessed on 29 July 2019 from https://www.cccmtl.gov.mo/files/plano_quinquenal_pt.pdf/

Nazarbayev, N. (2016). Keynote speech at the Saint Petersburg International Economic Forum on 17 June 2016.

Treaty on the Establishment of the Eurasian Economic Community, 10 October 2000.

World Trade Organization. (2015). Kazakhstan becomes the WTO's 162nd member on 30 November 2015. Accessed on 30 July 2019 from https://www.wto.org/ english/thewto_e/acc_e/a1_kazakhstan_e.htm 


\section{Journals}

Andronova, I. (2016). Eurasian Economic Union: Opportunities and Barriers to Regional and Global Leadership. International Organizations Research Journal, Vol. 11, No. 2.

Blanchard, J.M.F. \& Flint, C. (2017). The Geopolitics of China's Maritime Silk Road Initiative. Geopolitics, Vol. 22, No. 2.

Bratersky, M. (2016). Isolationism versus Geopolitics: The Dual Role of the Eurasian Eco- nomic Union in Global Governance. International Organizations Research Journal, Vol. 11, No. 2.

Diener, A.C. (2015). Parsing Mobilities in Central Eurasia: Border Management and New Silk Roads. Eurasian Geography and Economics, Volume 56, Number 4.

Dzarasov, R. (2016). The Global Crisis and Its Impact on the Eurasian Economic Union, European Politics and Society, no 17(S1).

Eliason, A. (2015). The Trade Facilitation Agreement: A New Hope for the World Trade Organization. World Trade Review, Volume 14, Number 4.

Ghouri, A. (2016). 'Towards Greater Integration? Legal and Policy Directions of Chinese Investments in Pakistan on the Advent of the Silk Road Economic Belt'. Chinese Journal of Comparative Law, Volume 4, Number 1.

Huang, H. (2017). 'The Role of Trust in China-ASEAN Relations Towards a Multi-Level Trust Building for China and ASEAN'. International Journal of China Studies, Volume 8, Number 1.

Kudaibergenova, D.T. (2016). Eurasian Economic Union Integration in Kazakhstan and Kyrgyzstan. European Politics and Society, Vol. 17, Sup. 1.

Lavrov, S. (2013). State of the Union Russia-EU: Prospects for Partnership in the Changing World. Journal of Common Market Studies, Number 51.

\section{Online Sources}

Chinese President Xi Jinping. (2015). Keynote Speech at the Boao Forum for Asia Annual Conference 2015. Accessed on 29 July 2019 from https://news.xinhuanet.com/english/2015-03/29/c_134106145.htm

CGTN. (2019). Second Belt and Road Forum to be held April 25-27 in Beijing. Accessed $\begin{array}{llll}\text { on } & 30 & \text { July } & 2019\end{array}$ https://news.cgtn.com/news/3d3d774d7945544d34457a6333566d54/index.html

Eurasian Commission. (2012). Memorandum of Cooperation in Trade Matters between the Eurasian Economic Commission and the Ministry of Commerce of the People's Republic of China on 6 December, 2012. Accessed on 30 July 2019 from http://www.

eurasiancommission.org/ru/act/trade/dotp/memorandymi/Documents/Mem4.pdf

Eurasian Economic Commission. (2014). Decision on initiation of negotiations with the People's Republic of China regarding conclusion of an agreement on exchange of information regarding goods and vehicles of international carriage carried across customs borders between the customs union and the People's Republic of China on 7 October 2014. Accessed on 24 July 2019 from https://docs.eaeunion.org/docs/en-us/0143556/clcd_07102014_186 
Eurasian Economic Commission. (2015). Joint Statement of the Eurasian Economic Commission and the Ministry of Commerce of the People's Republic of China on 8 May 2015. Accessed on 23 July 2019 from http://www.eurasiancommission.org/ru/act/trade/dotp/SiteAssets/ dostup/6.1.\%20\%D0\%A1\%D0\%BE\%D\%B2\%D0\%BC.\%D0\%B7\%D0\%B0\%D $1 \% 8 \mathrm{~F} \% \mathrm{D} 0 \% \mathrm{~B} 2 \% \mathrm{D} 0 \% \mathrm{BB} \% \mathrm{D} 0 \% \mathrm{~B}$ 5\%D0\%BD\%D0\%B8\%D0\%B5_\%D0\%A0\%D0\%A3\%D0\%A1.pdf

Eurasian Economic Commission. (2015). Development of Common Digital Space Opens a New Dimension of Cooperation between Eurasian Economic Union and Shanghai Cooperation Organization on 18 June 2015. Accessed on 27 July 2019 from https://www.eurasiancommission.org/ru/nae/news/Pages/18-06-20151.aspx

Eurasian Economic Community. (2006). Memorandum of understanding between the executive secretariat of EurAsEC and the secretariat of the Shanghai Cooperation Organization on 8 May 2006. Accessed on 1 August 2019 from https://www.evrazes.com/docs/view/299

Naryshkin, S. (2012). Eurasian Integration: Parliamentary Direction, 4 October. Accessed on 28 July 2019, from https://www.izvestia.ru/news/536755

Shanghai Cooperation Organization. (2016). Information Report on the Outcomes of the Meeting of the Council of Heads of Member States of the Shanghai Cooperation Organization on 23-24 June 2016, Tashkent, Uzbekistan. Accessed on 25 July 2019 from https://www.mfa. uz/en/press/scouzbekistan/sconews/7738

Shanghai Cooperation Organization. (2016). Brief Introduction to the Shanghai Cooperation Organization. Accessed on 28 July 2019 from https://en.scorussia.ru/ about_sco/20140905/1013180761.html

XINHUA. (2019). China, Russia Agree To Upgrade Relations For New Era. Accessed on 5 August 2019 from http://www.xinhuanet.com/english/201906/06/c_138119879_2.htm

Ziguo, L. (2019). Connecting the BRI with Eurasian Economic Union is strategic choice of China, Russia. Accessed on 28 July 2019 from https://news.cgtn.com/news/3d3d514d78676a4d34457a6333566d54/index.html 